\title{
Pengaruh Angin Dan Kelembapan Atmosfer Lapisan Atas Terhadap Lapisan Permukaan Di Manado
}

\author{
Farid Muftia,b*, As'aria \\ aJurusan Fisika, FMIPA, Unsrat, Manado \\ bBadan Meteorologi Klimatologi dan Geofisika
}

\begin{tabular}{l}
\hline K A T A K U N C I \\
\hline Angin \\
Kelembapan \\
Teknik korelasi
\end{tabular}

\begin{tabular}{l}
\hline K E Y W O R D S \\
\hline Wind \\
Humidity \\
Correlation technique
\end{tabular}

\begin{abstract}
A B S T R A K
Penelitian ini mengkaji lebih dalam kondisi angin dan kelembapan udara pada saat musim hujan dan musim kemarau di Manado dengan menggunakan data di lapisan permukaan dan data udara atas dari Stasiun Meteorologi Sam Ratulangi Manado. Tujuan utama dari penelitian ini adalah mendapatkan hubungan antara kondisi angin dan kelembapan lapisan atas terhadap lapisan permukaan, sehingga dapat memprakirakan kondisi angin dan kelembapan lapisan permukaan dengan berdasarkan keadaan lapisan atas. Metode yang digunakan adalah mengkomponenkan angin dalam arah utara-selatan dan timurbarat, selanjutnya mencari keterkaitan dengan menggunakan teknik korelasi. Hasil penelitian ini menunjukkan pada saat musim hujan angin pada lapisan $1500 \mathrm{~m}$ dan angin di lapisan permukaan memiliki arah yang sama dan saling menguatkan untuk komponen timur-barat (zonal) dengan koefisien korelasi $r=0,56$, sedangkan pada saat musim kemarau angin pada lapisan $1500 \mathrm{~m}$ dan angin di lapisan permukaan memiliki arah yang sama dan saling menguatkan untuk komponen utara-selatan (meridional) dengan koefisien korelasi $r=0,45$. Keterkaitan yang cukup kuat antara angin dengan kelembapan terjadi pada komponen $\mathrm{V}$ (meridional) yaitu, pada saat musim hujan, semakin besar kecepatan angin komponen negatif (utara) semakin besar pula kelembapan udara di lapisan permukaan, dengan koefisien korelasi benilai positif $r=0.40$. Pada saat musim kemarau, semakin besar kecepatan angin komponen positif (selatan) semakin kecil kelembapan udara di lapisan permukaan, dengan koefisien korelasi bernilai negatif $r=-0,48$.
\end{abstract}

A B S T R A C T

This study examined the wind and humidity condition in the rainy season and dry season in Manado by using the data in surface layer and upper air data from the Sam Ratulangi Meteorological Station. The primary objective of this study was to find the relationship between wind condition and upper layer humidity to surface layer, using correlation technique, in order to predict wind condition and humidity of the surface layer based on the condition of the upper layer. The results showed that, during the rainy season, the wind at layer $1500 \mathrm{~m}$ and surface layer had the same direction and mutually reinforced for the east-west component (zonal) with correlation coefficient $r=0.56$, whereas during the dry season, wind at layer $1500 \mathrm{~m}$ and at surface layer had the same direction and mutually reinforced for the north-south component (meridional) with correlation coefficient $r=0.45$. A relationship between wind and humidity was found at $\mathrm{V}$ component (meridional), which was, at rainy season, the higher the wind speed of negative component (north) the higher the humidity at surface layer with positive correlation coefficient $r=0.40$. At dry season, the higher

*Corresponding author: Jurusan Fisika FMIPA UNSRAT, Jl. Kampus Unsrat, Manado, Indonesia 95115; Email address: faridmufti87@yahoo.co.id Published by FMIPA UNSRAT (2014) 
the wind speed of positive component (south), the lower the humidity at the surface layer, with negative correlation coefficient $r=-0.48$.

AVAILABLE ONLINE

25 Februari 2014

\section{Pendahuluan}

Wilayah Indonesia adalah negara kepulauan terbesar di dunia. Terdiri dari 17.508 pulau besar dan kecil dengan panjang garis pantai total 43.670 mil atau $80.791 \mathrm{~km}$ sehingga wilayah Indonesia disebut sebagai "benua maritim" (maritime continent). Wilayah Indonesia masuk ke dalam wilayah tropis karena terletak di antara 23,5 Lintang Utara dan $23,5^{\circ}$ Lintang Selatan ${ }^{4)}$.

Indonesia dikenal memiliki dua musim, yaitu musim kemarau dan musim hujan. Musim kemarau umumnya terjadi ketika angin datang dari arah timur (disebut timuran). Periode aktif umumnya terjadi pada bulan April sampai September. Sementara musim hujan umumnya terjadi pada saat angin bertiup dari arah barat (disebut baratan). Periode aktif umumnya Oktober sampai Maret ${ }^{3}$.

Beberapa unsur iklim berfluktuasi mengikuti variasi musiman. Unsur angin merupakan unsur yang paling nampak mengikuti periode musiman yang berlangsung dan erat kaitannya dengan periode Monsun. Selain itu angin di permukaan juga memiliki variasi harian sesuai kondisi lingkungan, baik itu yang terjadi di wilayah pegunungan, lembah, pesisir, pedalaman, teluk, cekungan, dan lain-lain ${ }^{6}$.

Eksplorasi struktur suhu vertikal atmosfer dilakukan dengan pengukuran RASON (Radio sonde). Keadaan di mana terjadi penurunan suhu terhadap ketinggian yang bervariasi terhadap tempat, tetapi tidak melebihi $10^{\circ} / \mathrm{km}$ kecuali dekat permukaan tanah, disebut dengan susut suhu (lapse rate). Pada tahun 1902, Teisserenc de Bort (1855 -1913), ahli meteorologi Prancis dan Assmann (1845 -1918) ahli meteorologi Jerman, secara terpisah menemukan lapisan tinggi di atas $10 \mathrm{~km}$ di mana suhu naik sesuai dengan ketinggian ${ }^{5}$.

Lapisan atmosfer secara umum terbagi menjadi dua, pertama adalah atmosfer bebas (free atmosphere) menunjukkan kondisi angin sebenarnya, di mana efek kekasaran permukaan relatife kecil, ketinggiannya mulai dari 1000 meter keatas. Kedua adalah Atmospheric Boundary layer $(\mathrm{ABL})$ merupakan bagian terendah dari atmosfer dan karakteristikya secara langsung dipengaruhi oleh kontak dengan permukaan bumi, ketinggiannya di bawah 1000 meter. ABL biasanya dibagi menjadi dua lapisan, lapisan bawah disebut dengan lapisan permukaan (surface layer) ketinggian di bawah 10 meter, lapisan atas disebut dengan lapisan gesek (Ekman layer) ketinggian 10 sampai dengan 1000 meter ${ }^{1)}$.

Atmosfer di atas benua maritim Indonesia memainkan peranan penting dan unik dalam perubahan atmosfer global. Namun demikian, mekanisme pembangkitan gerak atmosfer masih sulit dipahami. Hal ini disebabkan kurangnya observasi atmosfer dan riset cuaca di wilayah tropis. Kerumitan dinamika atmosfer wilayah tropis dan keunikan atmosfer benua maritim menyebabkan kesulitan memprediksi cuaca dengan tingkat ketelitian yang tinggi, untuk itu perlu dikembangkan metode prediksi cuaca.

\section{Metode}

\subsection{Lokasi penelitian}

Penelitian ini dilakukan di Laboratorium Instrumentasi dan Geofosika Jurusan Fisika Universitas Sam Ratulangi dan Stasiun Meteorologi Sam Ratulangi, Badan Meteorologi Klimatologi dan Geofisika.

\subsection{Data penelitian}

1. Data lapisan permukaan pada tahun 2007 sampai dengan tahun 2012, terdiri dari arah dan kecepatan angin serta kelembapan diperoleh dari pengamatan permukaan.

2. Data lapisan atas pada tahun 2012, terdiri dari arah dan kecepatan angin serta kelembapan diperoleh dari pengamatan udara atas dengan Radiosonde yang dilakukan pada pukul 08.00 WITA, meliputi ketinggian 100, 800, 1000, 1500, 2000, 3000, 4500, 6000, 7500, 8500, 9500, 11000 meter.

\subsection{Metode penelitian}

1. Penguraian komponen angin dimaksudkan untuk mengetahui aktifitas angin zonal (Timut-barat) maupun meridional (utara-selatan) pada periode waktu sesuai dengan data yang didapat yaitu data angin lapisan permukaan dan data angin lapisan atas. Untuk memperoleh komponen angin zonal $(U)$ dan meridional $(V)$ dapat menggunakan persamaan berikut ${ }^{6)}$ :

$$
\begin{aligned}
& U=0,5 \cdot f f \cdot \cos (270-d d d) \\
& V=0,5 \cdot f f \cdot \sin (270-d d d)
\end{aligned}
$$

2. Selanjutnya dilakukan pengolahan data untuk memperoleh nilai rata-rata harian untuk kecepatan angin zonal, kecepatan angin meridional, dan kelembapan udara pada lapisan permukaan.

3. Membuat grafik, digunakan untuk mengetahui variasi rata-rata harian komponen angin maupun kelembapan di permukaan selama periode Januari sampai Desember 2012. Di mana $x$ merupakan fungsi waktu (tanggal) dan sumbu y merupakan nilai dari variabel $U$ dan $V$.

4. Memetakan Keadaan Angin dan Kelembapan. Pada sumbu x merupakan fungsi waktu dan sumbu y merupakan fungsi ketinggian. Pada 
koordinat $(\mathrm{x}, \mathrm{y})$ dicantumkan nilai data pada tanggal $x$ dengan ketinggian $y$. Setelah seluruh data dicantumkan, selanjutnya dibuat isoline (garis yang menghubungkan titik-titik dengan nilai yang sama) sehingga diperoleh kontur secara vertikal selama periode waktu tersebut.

5. Perhitungan koefisien korelasi ( $r$ ) dilakukan untuk mengetahui derajat hubungan linier antara dua kelompok data sampel. Adapun besarnya nilai koefisien korelasi $(r)$ dapat dihitung dengan menggunakan persamaan korelasi ${ }^{2)}$

$$
r(x, y)=\frac{\sum x y-\frac{1}{n} \Sigma x \Sigma y}{\left[\Sigma x^{2}-\frac{1}{n}(\Sigma x)^{2}\right]^{1 / 2}\left[\Sigma y^{2}-\frac{1}{n}(\Sigma y)^{2}\right]^{1 / 2}}
$$

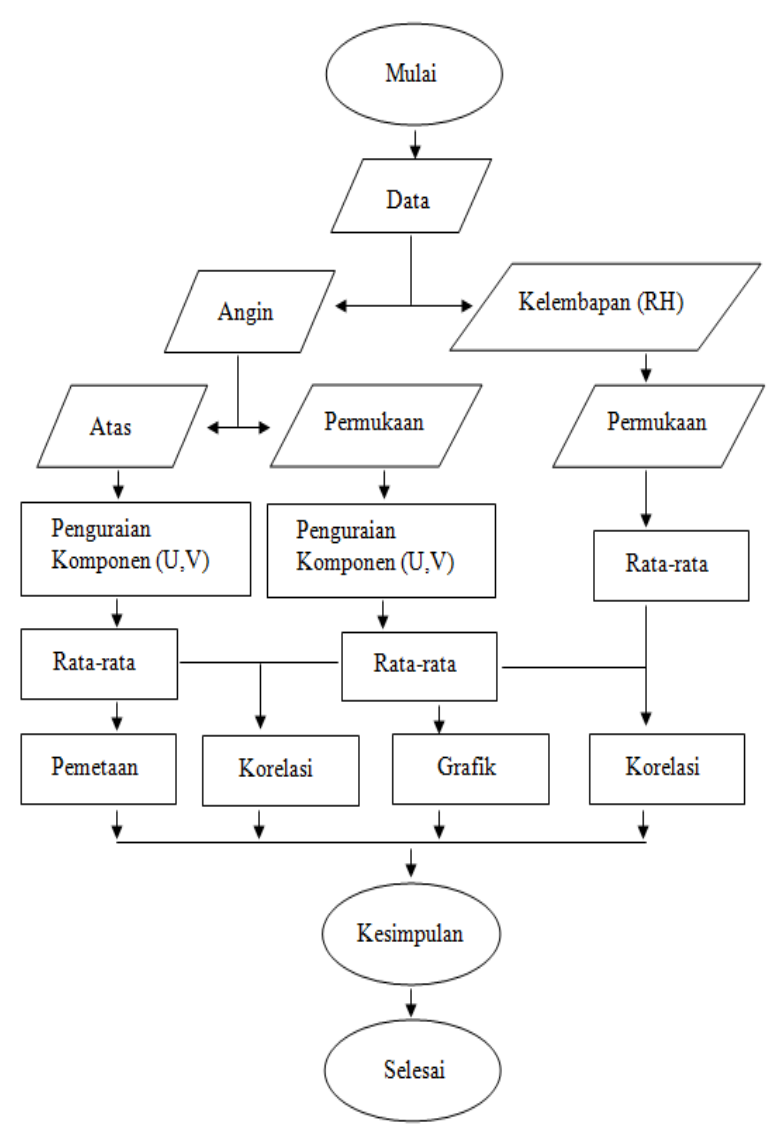

Gambar 1. Diagram alir penelitian

\section{Hasil dan Pembahasan}

\subsection{Komponen angin Zonal dan Meridional}

Penguraian komponen Zonal $(U)$ dan Meridional ( $V$ ) dalam satu hari diperoleh 24 komponen $U$ dan $V$, kemudian masing-masing komponen dalam satu hari di rata-ratakan. Komponen Zonal yang bernilai (+) dari arah barat, dan yang bernilai (-) dari arah timur. Untuk komponen Meridional yang bernilai (+) dari arah selatan, dan yang bernilai (-) dari arah utara.

\subsection{Grafik Komponen Zonal, Meridional dan Kelembapan}

Hasil perhitungan komponen angin tahun 2007-2011 yang telah diperoleh, nilai rata-ratanya digunakan untuk membuat grafik rata-rata atau grafik normal (Gambar 2). Komponen angin tahun 2012 nilai rata-rata setiap harinya dibuat grafik (Gambar 3).

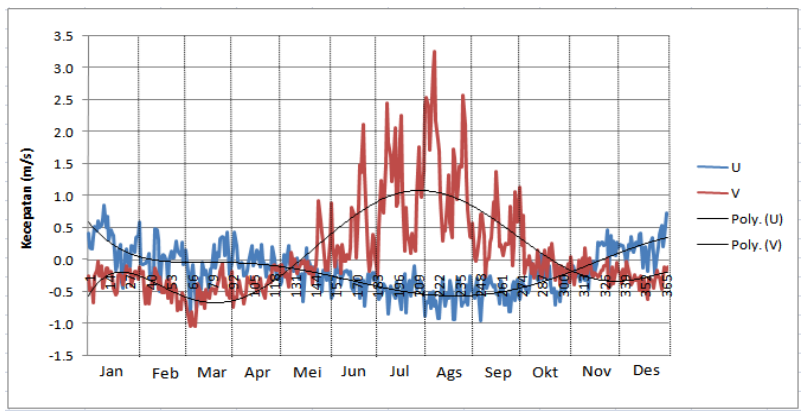

Gambar 2. Grafik normal komponen $U$ dan $V$

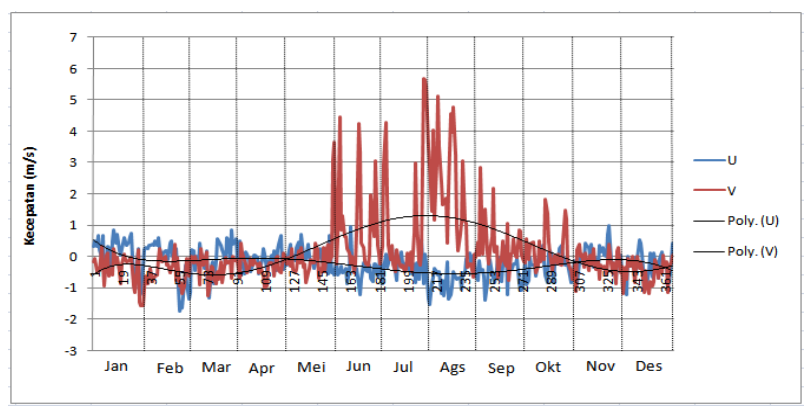

Gambar 3. Grafik komponen U dan V Tahun 2012

Pada Gambar 2, grafik meridional (V) yang bernilai negatif atau angin arah utara terlihat terjadi sekitar bulan Januari sampai April dan November sampai Desember dengan kecepatan maximum 1,0 $\mathrm{m} / \mathrm{s}$. Sedangkan yang bernilai positif atau angin arah selatan terjadi sekitar bulan Mei sampai dengan bulan Oktober dengan kecepatan maximum $3,3 \mathrm{~m} / \mathrm{s}$. Pada grafik zonal $(U)$ yang bernilai negatif atau angin arah timur terlihat terjadi sekitar bulan Mei sampai bulan Oktober dengan kecepatan maksimum 0,9 m/s. Sedangkan yang bernilai positif atau angin arah barat terjadi sekitar bulan Januari sampai April dan November, Desember dengan kecepatan maksimum 0,9 m/s. Kecepatan terbesar terjadi pada komponen selatan yaitu $3.3 \mathrm{~m} / \mathrm{s}$.

Kecepatan maksimum arah selatan memiliki kekuatan tiga kali lebih besar dibandingkan arah utara, timur dan barat. Setiap tahun, khusus pada saat musim kemarau Manado dan sekitarnya sering terjadi angin kencang dari arah selatan, dengan menganalisis angin dikomponen arah utara-selatan dan timur-barat dapat diketahui periode terjadinya angin selatan. Hasil sebelumya diperoleh bahwa periode angin selatan terjadi sekitar bulan Mei hingga Oktober.

Selain data angin, dibuat juga grafik untuk data kelembapan udara rata-rata di lapisan permukaan tahun 2012 (Gambar 4). 


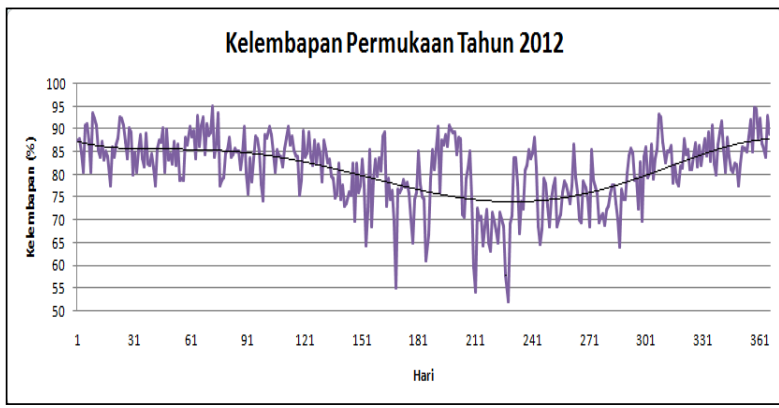

Gambar 4. Grafik Kelembapan

Secara umum kondisi angin di wilayah Indonesia sangat besar dipengaruhi oleh aktifitas Angin Monsun. Pada saat Musim Hujan, terlihat pada Gambar 4 di mana kelembapan udara cukup tinggi yaitu sekitar bulan November, Desember dan Januari hingga April betiup Angin Monsun Asia musim dingin. Pada saat Musim Kemarau bertiup Angin Monsun Australia musim dingin terjadi sekitar bulan Mei hingga Oktober, yang memiliki dampak kelembapan udara menjadi menurun.

\subsection{Kontur Komponen Zonal, Meridional dan Kelembapan}

Hasil perhitungan komponen angin lapisan atas tahun 2012 yang telah diperoleh, kemudian dibuat kontur dengan menggunakan bantuan software Surfer 9.0. (Gambar 5 dan Gambar 6). Data rata-rata harian kelembapan udara lapisan atas juga dibuatkan kontur seperti pada Gambar 7 .

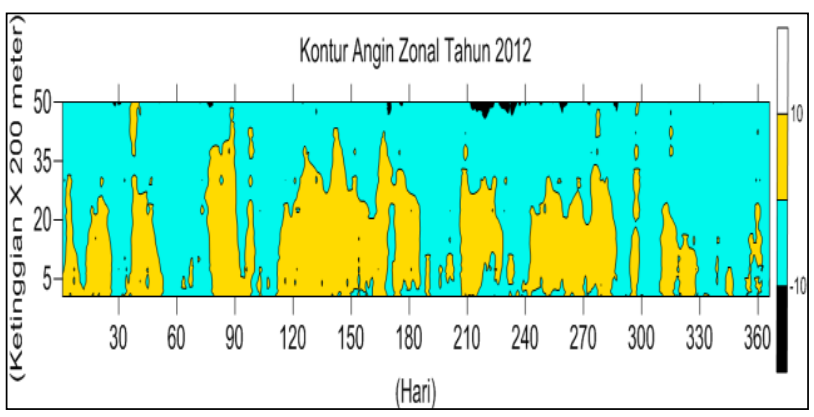

Gambar 5. Kontur angin komponen $U$

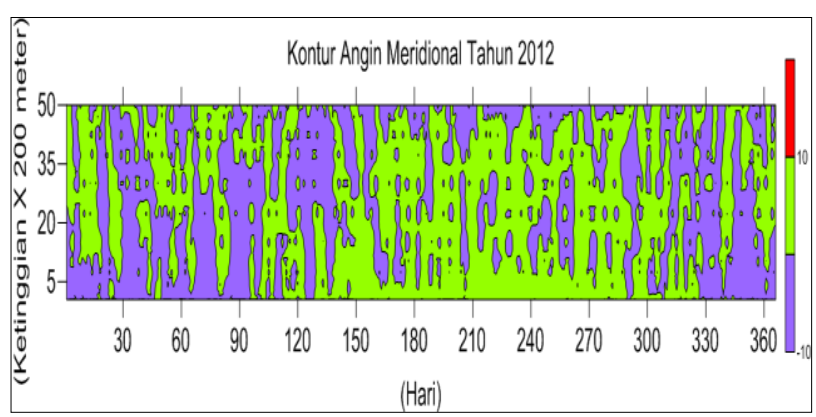

Gambar 6. Kontur angin komponen $V$

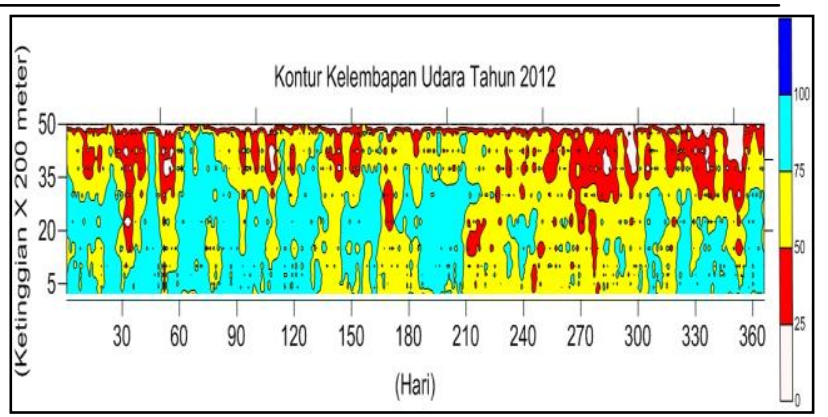

Gambar 7. Kontur kelembapan

Kkontur medan angin komponen zonal (Gambar 5) membuktikan teori tentang sirkulasi zonal. Diketahui terdapat sirkulasi zonal yang menggambarkan pergerakan udara pada arah sejajar dengan lintang bumi. Sikulasi Walker adalah salah satu Sirkulasi Zonal (timur-barat) yang terjadi di sepanjang ekuator. Pada tahun normal, sirkulasi ini ditandai oleh kenaikan udara di Samudera Pasifik ekuator bagian barat dekat dengan benua maritim Indonesia dan penurunan udara di Samudera Pasifik ekuator bagian timur lepas pantai Amerika Selatan. Kontur komponen zonal menunjukkan sebagian besar pada lapisan bawah angin bertiup dari arah barat, sedangkan lapisan di atasnya dari arah timur.

Kontur medan angin komponen meridional (Gambar 6) menunjukkan suatu pola di mana pada sekitar bulan bulan Mei (hari ke-130) hingga akhir Oktober, angin secara dominan dari arah selatan. Sedangkan pada bulan Januari hingga Mei (hari ke130) dan awal November hingga akhir Desember, angin dominan dari arah utara. Pembahasan sebelumnya, kondisi angin lapisan permukaan pada komponen selatan memiliki kecepatan angin yang cukup besar menunjukkan kondisi yang sama oleh angin lapisan di atasnya.

Kontur kelembapan udara lapisan atas (Gambar 7), yang merupakan analisis grafik kelembapan permukaan (Gambar 4), menunjukkan keterkaitan antara kondisi kelembapan di permukaan dengan kondisi kelembapan lapisan atasnya. Selanjutnya kaitan antara angin dan kelembapan lapisan atas dengan angin dan kelembapan lapisan permukaan dicari dengan menggunakan rumus korelasi.

\subsection{Metode Korelasi}

\subsubsection{Korelasi Angin 1500 meter dengan angin permukaan}

Pada persamaan korelasi diketahui variabel $x$ adalah angin lapisan 1500 meter dan variabel $y$ adalah angin lapisan permukaan. Hasil korelasi pada komponen $U$ dapat dilihat pada Gambar 8 dan komponen $V$ pada Gambar 9. 


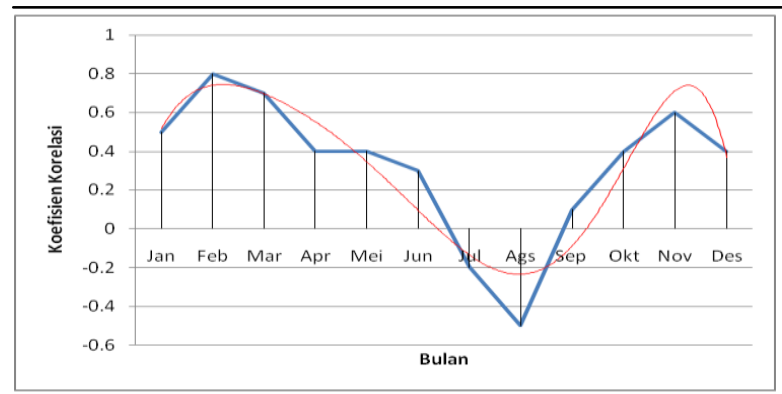

Gambar 8. Grafik korelasi komponen $U$

Gambar 8 menunjukkan bahwa korelasi yang cukup antara angin 1500 meter dengan angin permukaan pada komponen $U$ (Zonal) dengan koefisien korelasi positif, terjadi pada musim hujan. Pada saat musim hujan dan aktifnya angin monsun Asia, sehingga angin di daerah Manado umumnya dari arah timur laut. Karena mendapatkan nilai korelasi yang positif dapat diartikan angin monsun Asia memberikan pengaruh yang sama terhadap kondisi angin 1500 meter dan yang terjadi di lapisan permukaan.

Pada musim kemarau dengan koefisien korelasi bernilai negatif artinya arah angin tidak searah. Angin di permukaan terlihat dominan dari arah timur sedangkan di lapisan 1500 meter dominan dari arah barat sehingga diperoleh koefisien korelasi bernilai negatif. Angin monsun Australia menyebabkan angin di daerah Manado umumnya dari arah barat daya. Angin monsun Australia memberikan pengaruh pada lapisan 1500 meter sedangkan di permukaan tidak berpengaruh.

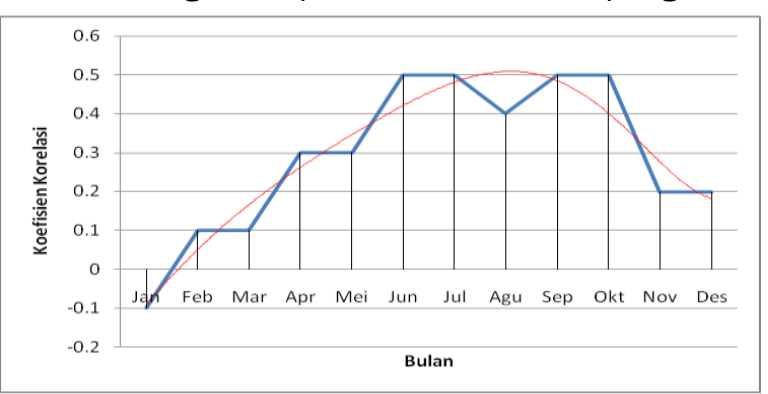

Gambar 9. Grafik korelasi komponen $V$

Gambar 9 menunjukkan bahwa korelasi yang cukup antara angin 1500 meter dengan angin permukaan pada komponen $V$ (Meridional) dengan koefisien korelasi bernilai positif terjadi pada musim kemarau. Pada saat musim kemarau bersamaan dengan aktifnya angin monsun Australia, sehingga angin di daerah Manado umumnya dari arah barat daya. Karena mendapatkan nilai korelasi yang positif dapat diartikan angin monsun Australia memberikan pengaruh yang sama terhadap kondisi angin 1500 meter dan yang terjadi di lapisan permukaan. Pada saat musim kemarau angin lapisan 1500 meter memiliki arah yang sama dengan angin di permukaan.

Nilai korelasi yang sangat kecil terjadi di musim hujan, Angin lapisan 1500 meter terlihat dari arah utara sedangkan angin di lapisan permukaan cenderung tenang dan hanya sedikit bertiup dari arah utara. Pada saat musim hujan angin lapisan 1500 meter kurang memiliki kaitan dengan angin di permukaan untuk komponen $V$ (Meridional). Angin monsun Asia yang secara umum dari arah arah timur laut di Manado hanya mempengaruhi lapisan 1500 meter, dan sedikit pengaruhnya di lapisan permukaan.

\subsubsection{Korelasi Angin dengan Kelembapan}

Pada persamaan korelasi diketahui variabel $x$ adalah komponen angin dan variabel $y$ adalah kelembapan pada lapisan permukaan. Hasil korelasi pada komponen $U$ dengan kelembapan dapat dilihat pada Gambar 10, dan untuk komponen $V$ pada Gambar 11.

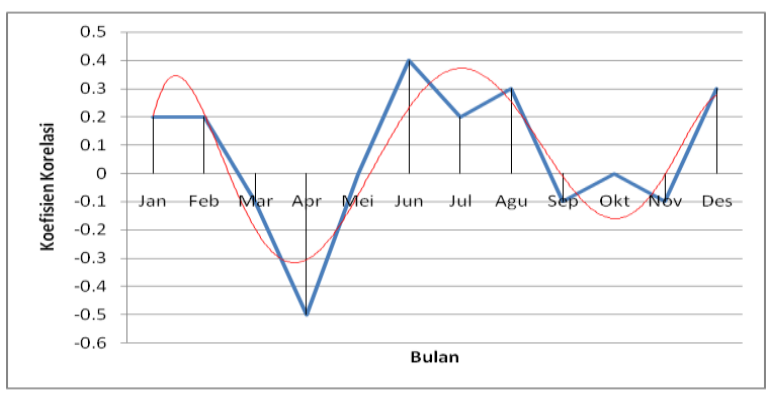

Gambar 10. Grafik korelasi komponen $U$ dengan kelembapan

Gambar 10 menunjukkan bahwa korelasi yang cukup dengan koefisien korelasi bernilai negatif hanya terjadi pada bulan April. Karena dari grafik tidak terlihat pola yang jelas, sehingga pada musim kemarau dan musim hujan komponen $U$ tidak memiliki keterkaitan antara angin komponen $U$ (zonal) dengan kelembapan udara di permukaan.

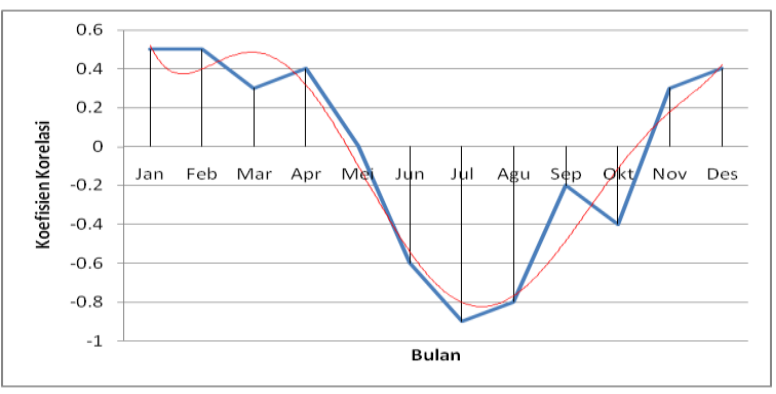

Gambar 11. Grafik korelasi komponen $V$ dengan kelembapan

Gambar 11 menunjukkan bahwa korelasi yang cukup antara angin permukaan pada komponen $V$ (Meridional) dengan kelembapan udara dengan koefisien korelasi bernilai positif terjadi pada musim hujan. Pada saat musim hujan di mana angin komponen $V$ (meridional) dominan bertiup dari arah utara memiliki keterkaitan dengan tingginya kelembapan udara. Sedangkan pada musim kemarau koefisin korelasi bernilai negatif, artinya korelasi berbanding terbalik sehingga pada saat musim kemarau di mana angin komponen $V$ (Meridional) dominan bertiup dari arah selatan memiliki keterkaitan dengan rendahnya kelembapan udara. 


\section{Kesimpulan}

\subsection{Kesimpulan}

Berdasarkan uraian tersebut di atas maka dapat disimpulkan bahwa:

1. Pada saat musim hujan angin pada lapisan 1500 meter dengan angin di lapisan permukaan memiliki arah yang sama dan saling menguatkan untuk komponen timur-barat (zonal) dengan koefisien korelasi $(r=0,56)$ Sedangkan komponen utara-selatan (meridional) berhubungan lemah, di mana koefisien korelasi $(r=0,08)$.

2. Pada saat musim kemarau angin pada lapisan 1500 meter dengan angin di lapisan permukaan memiliki arah yang sama dan saling menguatkan untuk komponen utara-selatan (meridional) dengan koefisien korelasi $(r=0,45)$. Sedangkan komponen timur-barat (zonal) berhubungan lemah, di mana koefisien korelasi $(r=0,13)$.

3. Komponen utara-selatan memiliki keterkaitan dengan kelembapan udara, di mana pada saat musim hujan semakin besar kecepatan angin komponen negatif (utara) semakin besar pula kelembapan udara di lapisan permukaan, dengan koefisien korelasi benilai positif $(r=0,40)$. Pada saat musim kemarau semakin besar kecepatan angin komponen positif (selatan) semakin kecil kelembapan udara di lapisan permukaan, dengan koefisien korelasi bernilai negatif $(r=-0,48)$. Untuk komponen timur-barat (zonal) berhubungan lemah terhadap kelembapan udara.

\section{Daftar Pustaka}

1) Anonymous. 2013. Lapisan Ekman. http:// apollo.Isc.vsc.edu [25 Februari 2013].

2) Hernowo, B. 1999. Praktek Statistik Meteorologi, Penerbit Badan Diklat Akademi Meteorologi dan Geofisika. Jakarta.

3) Soepangkat. 1992. Meteorologi Umum. BPLMG. Jakarta.

4) Tjasyono, B.HK. 2006. Meteorologi Indonesia. Badan Meteorologi Klimatologi dan Geofisika. Jakarta.

5) Tjasyono, B.HK. 2008. Meteorologi Terapan. 2008. Penerbit ITB. Bandung.

6) Yunus, S., A. Zakir, dan Karlina. 2004. Keadaan Cuaca Pada Musim Transisi. 